
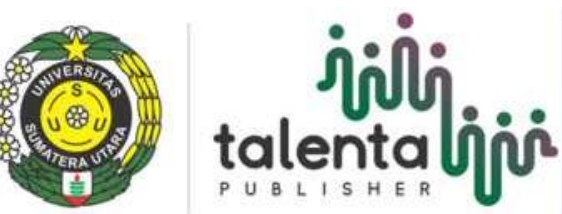

\title{
Digestibility Of Maggot Black Soldier Fly (Hermetiallucens) Flour in Ration Of Kampong Chicken
}

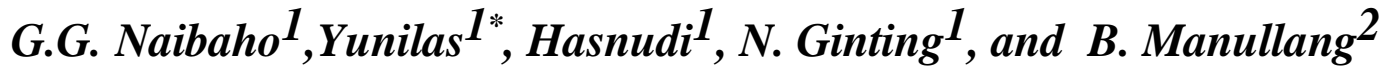 \\ ${ }^{1}$ Animal Production Program Study, Faculty of Agriculture, Universitas SumatraUtara,Padang Bulan, \\ Medan 2015 \\ ${ }^{2}$.Research Assistant at Academia Sinica Genomic Research Center, Taiwan \\ *Correspondent Author:yunilas@usu.ac.id
}

\begin{abstract}
Good quality animal feed was a determining factor for the success of livestock industry. Maggot BSF had the potential as a promising protein source feed. The aimed of this researceh was to investigate digestibility of crude protein, dry matter, organic matter of BSF maggot flour. The maggot was kept in media of fermented palm oil coir (FPOC) with dose of fermenter 1, 3, 5\%. The maggot processed into flour and fed to kampong chickens. The reseach was conducted experimentally using a completely randomized design (CRD) with 4 treatments and 5 replications. The treatments were: M0 (fish meal), M1 (Maggot FPOC 1\%), M2 (maggot FPOC 3\%) and M3 (maggot FPOC 5\%). Based on the results of the study, it was found that BSF had a significant effect $(\mathrm{P}<0.05)$ on protein digestibility $(\mathrm{M} 0=75.70, \mathrm{M} 1=63.03, \mathrm{M} 2=73.32$, and $\mathrm{M} 3=56.24)$, a very significant effect $(\mathrm{P}$ $<0.01)$ on the digestibility of dry matter $(\mathrm{M} 0=64.72, \mathrm{M} 1=44.08, \mathrm{M} 2=44.26$, and $\mathrm{M} 3=37.43)$, and the digestibility of organic matter $(\mathrm{M} 0=68.59, \mathrm{M} 1=45,32, \mathrm{M} 2=48.08$, and $\mathrm{M} 3=47.47)$. Maggot flour from FPOC $3 \%$ produced good crude protein digestibility in kampong chicken compared to FPOC $1 \%$ and $3 \%$.
\end{abstract}

Keywords: digestibility, maggot black soldier fly, palm oil coir

Received [6 January 2021] | Revised [9 February 2021] | Accepted [9 March 2021]

\section{Introduction}

Provision of good quality animal feed was one of the determining factors for the success of the livestock industry and is the largest component in this business activity, namely around 50-70\% [1]. The main raw material for protein that was most often used is fish meal which contains $58-68 \%$ protein [2]. However the availability of fish meal is fluctuates, therefore it maycause price increases. This problems need to find alternatives for feed ingredients as a protein source. One of which is protein derived from insects, namely the maggot Black Soldier Fly (BSF).

BSF maggot cultivation can be done using media that contains organic materials. Oil palm is one of the most widely grown vegetable oil-producing crops in Indonesian plantations, therefore palm oil coir had the potential to be used as a BSF maggot growth medium, but processing was still necessary to increase the crude protein content and crude fiber in palm oil coir [3].

Black Soldier Fly had a very promising potential as a feed source of protein, this makes the use of insects as a protein source had been widely discussed by researchers in the world suchas [4]. Maggot can replace fish meal in broiler chicken production and positively affects the weight growth and 
digestibility of chickens [5]. The protein content in larvae is quite high, namely $45.6 \%$ with a fat content $29.65 \%$ [6].

The high protein content in maggots from the BSF does not guarantee the high level of protein availability in it. According to [7] the high and low digestibility of feed ingredients means how much feed ingredients contain nutrients in a form that can be digested in the digestive tract. The aims of the research to investigate digestibility crude protein, dry matter and organic matter of maggot BSF flour from the results of rearing in fermented palm coir media. The BSF flour than was given as feed for kampong chickens. The result of this research couldbe a novel finding since palm oil coir are waste and by this research the coir became usefull as amedia of maggot BSF for feed industry.

\section{Materials and Methods}

\subsection{Materials}

The materials used were fish meal, maggot which comes from the results of maintenance in fermented palm coir media with different doses of MOL $(1 \%, 3 \%, 5 \%)$, as many as 20 kampong chickens aged 4-5 months with body weight $1-1.5 \mathrm{~kg}$, rodalon, water, boric acidwith a concentration of $5 \%$. The tools used were containers, modified disposibles, polyethylene plastic, measuring cups, cameras as documentation tools, gloves, masks, ovens for drying maggot, grinder to smooth maggot into flour, digital scales for weighing materials, cages 20 units of metabolic modification with a size of $20 \mathrm{~cm} \times 20 \mathrm{~cm} \times 35 \mathrm{~cm}$ for a chicken holder, plasticfor fecal storage.

\subsection{Research Methods}

The research was carried out experimentally using a completely randomized design (CRD) consisting of 4 treatments and 5 replications, which were tested with the following treatments :

M0: Fish Meal (Control)

M1: Maggot BSF flour from by media of FPOC $1 \%$

M2: Maggot BSF flour from by media of FPOC 3\%

M3: Maggot BSF flour from by media of FPOC 5\% 


\section{Research Parameters}

The parameters observed included protein digestibility, dry matter, and organic matter

1. Crude Protein Digestibility (CPD)

2. Dry Matter Digestibility (DMD)

3. Organic Matter Digestibility (OMD)

\section{Result and Discussion}

\subsection{Crude Protein Digestibility}

Digestibility is the percentage of nutrients that are absorbed in the digestive tract which can be seen by looking at the difference between the amount of nutrients eaten and the amountof nutrients excreted in feces [8]. The results of the average crude protein digestibility in the treatment are shown in "Table 1" below.

Table 1. Crude protein digestibility values due to application of maggot flour reared in FPOC.Treatments

\begin{tabular}{ccccccc}
\hline & \multicolumn{5}{c}{ Replications } & \multirow{2}{*}{ Mean } \\
\cline { 2 - 5 } & 1 & & 3 & 4 & 5 & \\
\hline M0 & 78,72 & 71,78 & 76,86 & 83,65 & 67,51 & $75,70^{\mathrm{b}}$ \\
M1 & 64,51 & 75,45 & 59,92 & 48,91 & 66,37 & $63,03^{\mathrm{ab}}$ \\
M2 & 66,70 & 66,38 & 71,59 & 81,88 & 80,06 & $73,32^{\mathrm{b}}$ \\
M3 & 66,04 & 49,88 & 70,32 & 30,87 & 64,07 & $56,24^{\mathrm{a}}$ \\
\hline \multicolumn{2}{l}{ Note: different superscripts in the same column show significant differences $(\mathrm{P}<0.05)}$.
\end{tabular}

Note: different superscripts in the same column show significant differences $(\mathrm{P}<0.05)$.

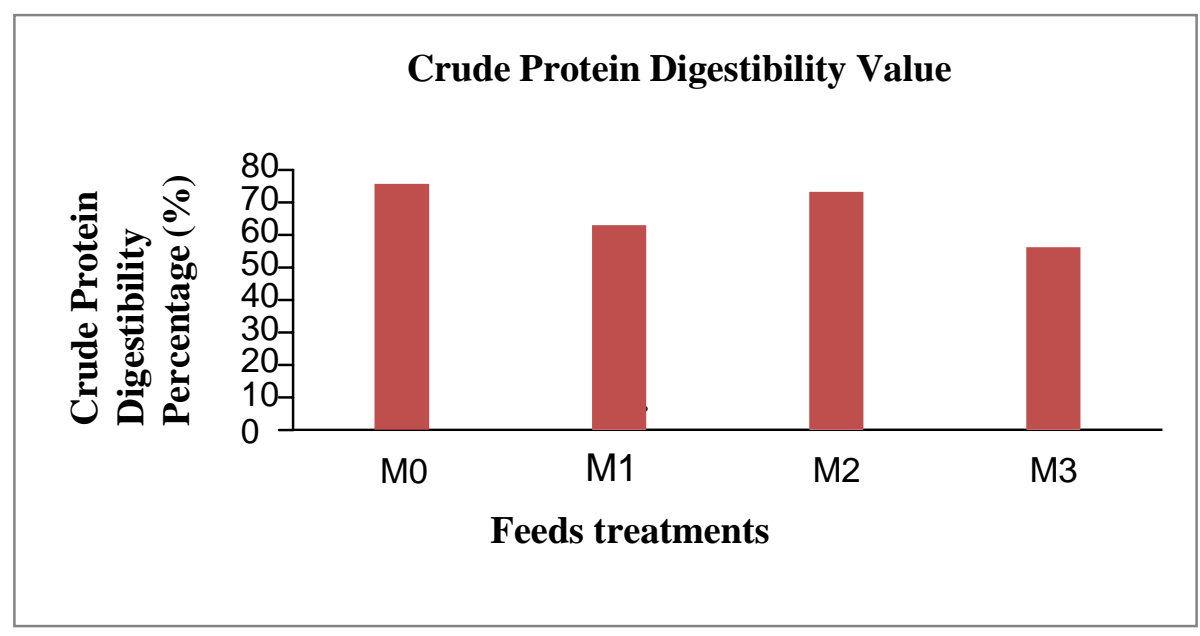

Figure 1. Crude protein digestibility(\%) due to application of maggot flour reared in FPOC 
The mean value of crude protein digestibility ranged from $56.24-75.70 \%$. CP digestibility of maggot BSF flour from the results FPOC various fermenter dose ranged from $56.24-73.32 \%$ and CP digestibility of fish meal as a control was $75.70 \%$. The result of the research M0, M1 and M2 treatments significantly different to M3 treatments. This indicates that the protein content of M0 and M1, M2 derived from maggot flour is higher than M3 treatment.

[9] Stated that differences in the digestibility of crude protein in each treatment were influenced by several factors, namely the protein content of feed ingredients, the protein content that enters the digestive tract and the amount of ration consumption.

The low protein content in the M3 treatment was due to the high crude fiber so that the maggots that breed in the media are difficult to digest foods that are still high in fiber. This is in accordance with research [3] which states that crude fiber in FPOC 5\% was 36.60\%. This proves that each dose given is different to the maggot growth media will affect the nutritional value of the BSF Maggot. This is in accordance with the statement [10] that the quality and quantity of development media for fly larvae greatly affects the nutrient content of the body and the survival of the larvae and subsequent metamorphosis stages.

Based on the results of the study, it can be seen that the value of crude proteindigestibility in treatment M0 (75.70\%) and M2 (73.32\%) is classified as high, treatment M1 (63.03\%) is classified as moderate and has met the standard of good feed digestibility for poultry but in M3 treatment (56.24\%) is classified as low. This is in accordance with [11] stated that the quality of the ration based on digestibility is divided into 3 categories, namely: the digestibility value in the range of $50-60 \%$ is low quality, $60-70 \%$ is medium quality and above $70 \%$ is high quality.

\subsection{Dry Matter Digestibility}

Dry matter digestibility is the digestibility of all food substances that can be digested bypoultry. This is in accordance with the statement [9] stated that dry matter digestibility is measured to determine the amount of food substances absorbed by the body which is carried out through an analysis of the amount of dry matter, both in rations and feces. The results of the dry matter digestibility average in the treatment are shown in "Table 2" below.

Table 2. Dry Matter Digestibility due to application of maggot flour mentation in FPOC.

\begin{tabular}{ccccccc}
\hline \multirow{2}{*}{ Treatments } & \multicolumn{5}{c}{ Replications } & \multirow{2}{*}{ Mean } \\
\cline { 2 - 5 } & 1 & 2 & 3 & 4 & 5 & \\
\hline M0 & 66,51 & 60,03 & 65,92 & 73,52 & 57,60 & $64,72^{\mathrm{B}}$ \\
M1 & 43,14 & 58,59 & 41,58 & 36,82 & 50,27 & $44,08^{\mathrm{A}}$ \\
M2 & 27,06 & 35,83 & 44,43 & 57,14 & 56,86 & $44,26^{\mathrm{A}}$ \\
M3 & 41,63 & 24,12 & 48,10 & 29,89 & 43,39 & $37,43^{\mathrm{A}}$ \\
\hline
\end{tabular}

Note: different superscripts in the same column show very significant differences $(\mathrm{P}<0.01)$. 


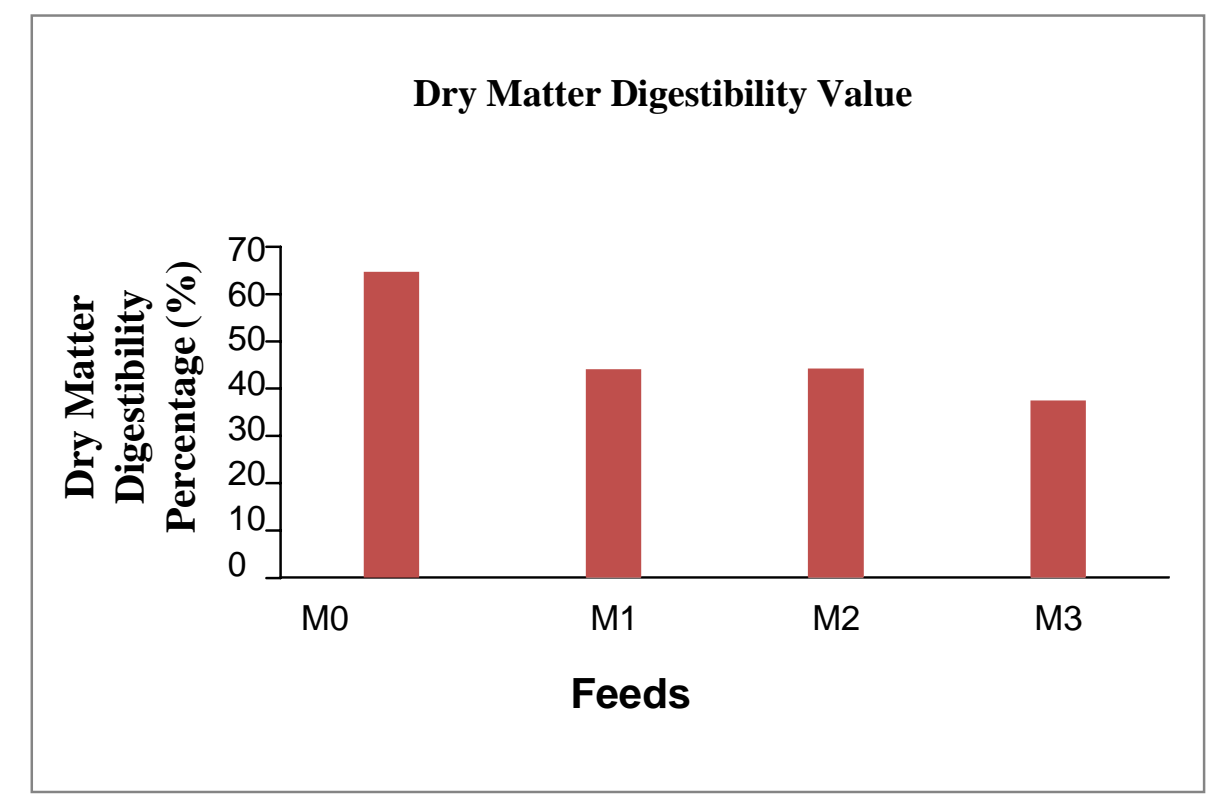

Figure 2. Dry Matter Digestibility (\%) of treatment

The average value of the dry matter digestibility of the treatment ranged from 37.43 to $64.72 \%$. The DM digestibility of maggot flour from the results FPOC various MOL doses ranged from $37.43-44.26 \%$ and the DM digestibility of fish meal as a control was $64.72 \%$. Based on Duncan's continued test, it was seen that the control treatment using fish meal was significantly different from the treatment of M1, M2, M3. The high value of dry matter digestibility in M0 treatment was due to the high value of crude protein digestibility in M0 treatment, and the low dry matter digestibility value in M3 treatment was due to the low value of crude protein digestibility in M3 treatment. It is assumed that the digestibility value of dry matter is directly proportional to the digestibility of crude protein, because protein is one of the compositions contained in dry matter. This is in accordance with the statement [12] which states that the digestibility value of protein is closely related to the digestibility of the dry matter of theration, where the digestibility value of protein is directly proportional to the digestibility of the dry matter of the ration or vice versa.

The low digestibility of M1, M2 and M3 treatment compared to M0 treatment is due to the influence of the activity of the chitin substance found in maggot flour. This is in accordance with statements [13] and [14] which state that the digestibility level of insect nutrients in broilers varies and is determined by several factors, namely insect species and chitin content.

\subsection{Organic Matter Digestibility}

The digestibility of the organic matter of a feed shows the quality of the feed that willbe digested by the body of the animal. The average digestibility results of organic matter in the treatment can be seen in "Table 3" below: 
Table 3. Organic Matter Digestibility due to Application of Maggot Flour Reared in FPOC.

\begin{tabular}{ccccccc}
\hline \multirow{2}{*}{ Treatments } & \multicolumn{5}{c}{ Replications } & \multirow{2}{*}{ Mean } \\
\cline { 2 - 5 } & 1 & 2 & 3 & 4 & 5 & \\
\hline M0 & 68,22 & 66,55 & 68,55 & 75,72 & 63,93 & $68,59^{\text {в }}$ \\
M1 & 39,80 & 53,44 & 39,96 & 43,79 & 49,61 & $45,32^{\text {A }}$ \\
M2 & 32,04 & 42,11 & 48,22 & 58,19 & 59,84 & $48,08^{\text {A }}$ \\
\hline M3 & 49,75 & 52,14 & 55,67 & 33,57 & 44,23 & $47,47^{\text {A }}$ \\
\hline
\end{tabular}

Note: different superscripts in the same column show very significant differences $(\mathrm{P}<0.01)$.

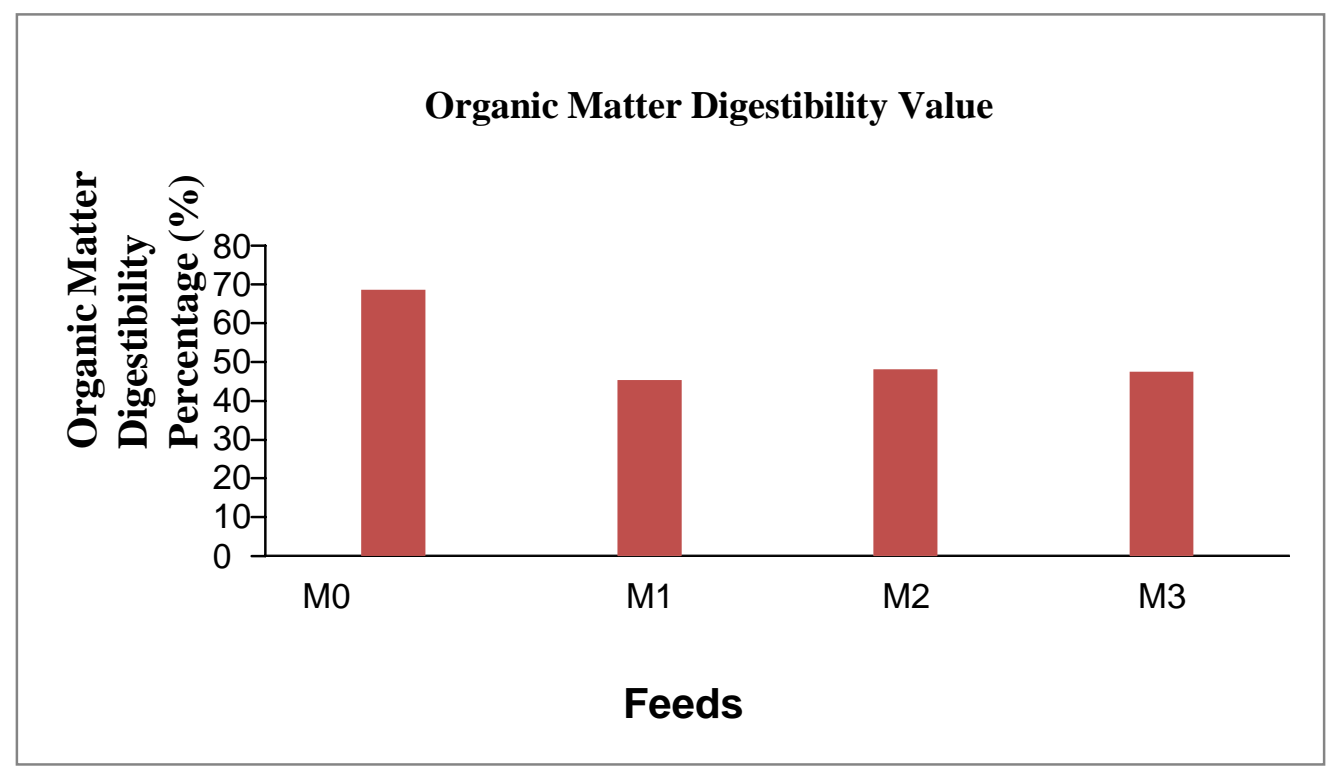

Figure 3. Organic Matter Digestibility (\%) treatment

The OM digestibility of maggot flour from the results FPOC with various MOL doses ranged from 45.32 to $47.47 \%$ and OM digestibility of fish meal as a control was $68.59 \%$. Based on Duncan's continued test, it was seen that the control treatment using fish meal was significantly different from the treatment of M1, M2 and M3. The highest organic matter digestibility value was in the M0 treatment ( $68.59 \%$ ), then followed by the M2 treatment (48.08\%), then followed by M3 treatment $(47.47 \%)$ and the lowest digestibility of organic matter was found in the M1 treatment (45.32\%). The high digestibility value of organic matterin M0 treatment is in line with the high dry matter digestibility value in M0 treatment. This is in line with the principle of calculating organic matter from proximate analysis, where the higher the percentage of dry matter, the higher the percentage of organic matter will be followed [15].

[16] added that the increase in the digestibility of organic matter is in line with the increase in the digestibility of dry matter, because most of the dry matter components consist of organic matter, so the factors that influence the level of dry matter digestibility will also affect the level of organic matter. Based on the results of the study, it can be seen that the digestibility values of organic matter in the treatment of M0 (68.59\%) and M2 (48.08\%) were classified as normal, treatment of M1 $(45.32 \%)$ and M3 (47.47\%) were classified as low. This is in accordance with the statement [17] which states that the normal range of the organic matter digestibility of a feedingredient is in the range of $48.26-53.75 \%$. 


\section{Conclusion}

The results showed that maggot BSF flour from the results FPOC dose of 3\% MOL(M2) resulted in good crude protein digestibility in kampong chickens.

\section{REFERENCES}

[1] Katayane AF, Wolayan FR, Imbar MR. Production and protein content of maggot (Hermetiaillucens) using different growing media. J Zootek. 34: 27-36. 2014.

[2] Sitompul, S. Analysis of Amino Acids in Fish Meal and Soybean Meal. Agricultural Engineering Bulletin. Vol. 9. No. 1: 33-37. 2004.

[3] Wicaksono, A. Fermentation of oil palm coir waste with local microorganisms (MOL) on the nutrient content of the media and the production of maggot black army fly (hermetia illucens). Essay. Faculty of Agriculture. University of Northern Sumatra. 2020.

[4] Wang D, Shao WZ, Chuan XZ, Yao YB, Shi HA, Ying NX. Evaluation on nutritional value of field crickets as a poultry feedstuff. Asian Australas J Anim Sci. 18:667-670. 2005.

[5] Teguai, A., M. Mpoame, J. A. Okourou Mba. Production performance of broiler birds as affected by the replacement of fish meal by maggot meal in the starter and finisher diets. Tropicultura. 20 (4): 187-192. 2002.

[6] Fahmi, M. R., Saurin H. and Wayan S. Potential of Maggots as a Source of Fish FeedProtein. Research Workshop on Freshwater Ornamental Fish Cultivation, Depok. 2007

[7] Ismail, R., In Vitro Digestibility, http: // rismanismail2. wordpress.com/ 2011/05/22/digestibilityvalues-part-4 / \# more-310. [Wednesday, February 13, 2013]. 2011.

[8] Anggorodi. 2005. General Forage Science. PT. Gramedia. Jakarta

[9] Boangmanalu.R., Tri Hesti Wahyuni., Sayed Umar. 2016. Digestibility of dry matter, organic matter and coarse protein of rations that contain cork fish waste flour (Butis amboinensis) as a substitute for fish meal in broilers. Journal of Integrative Animal Husbandry Vol. 4 No.3 August 2016: 329-340.

[10] Gobbi P, Martínez-Sánchez A, Rojo S. The effects of larval diet on adult life-history traits of the Black Soldier Fly, Hermetia illucens (Diptera: Stratiomyidae). Eur J Entomol. 110:461-468. 2013

[11]Anggorodi. R. 1994. Nutrition of Various Poultry. PT. Gramedia Pustaka Utama.Jakarta.

[12] Rambet, V., J.F Umboh., Y. L. R. Tulung., And Y. H. S. Kowel. Protein Digestibility and Energy of Broiler Rations Using Manggot Flour (Hermetia Illucens) as a substitute for fish meal. Zootek Journal Vol. 36 No. 1: 13-12. 2016.

[13] De Marco M, S Martinez, F Hernandez, J Madrid, F Gai, L Rotolo, M Belforti, D Bergero, HKatz and S Dabbou. Nutritional value of two insect larval meals (Tenebrio molitor and Hermetia illucens) for broiler chickens: Apparent nutrient digestibility. apparent ileal amino acid digestibility and apparent metabolizable energy. Anim Feed Sci Technol. 209:211-218. 2015.

[14] Schiavone A, De Marco M, Martínez S, Dabbou S, Renna M, Madrid J and Gasco L. Nutritional value of a partially defatted and a highly defatted black soldier fly larvae (Hermetia illucens L) meal for broiler chickens: apparent nutrient digestibility. apparent metabolizable energy and apparent ileal 
amino acid digestibility. J Anim Sci Biotechnol. 8:51. 2017.

[15] Bautrif, E. Recent Development in Quality Evaluation. Food Policy an Nutrition Division, FAO, Rome. 1990

[16] Sutardi, T. Basis of Nutrition Science Volume 1. Department of Animal Feed Science. Faculty of Agriculture, IPB. Bogor. 1980.

[17] Firsoni, J., Sulistyo, A. S. Tjakradiraja, and Suharyono. In Vitro Fermentation Test on the Effect of Feed Supplements in Complete Diets. Isotope and Radiation Technology Application Center, BATAN. Faculty of Animal Husbandry, Bogor Agricultural University.Pages: 233-240.2008. 